\title{
Constructing Networks of Trust? The Case of the Energy Community in Southeast Europe
}

\author{
Daniel Göler and Kristina Kurze*
}

\begin{abstract}
This article investigates whether the Energy Community founded in 2005 has contributed to the peace and reconciliation process in Southeast Europe. The analysis is mainly informed by sociological institutionalism, which contends that institutions may change actors' perceptions, identities and interests. By analyzing cooperation within the Energy Community we seek to trace whether the continuous interaction among the members has led to changes in their mutual perceptions and hence helps to overcome historical burdens. The empirical analysis focuses on two critical cases of cooperation: The handling of Kosovo's independence declaration in February 2008 and the management of the gas crisis in January 2009. The case studies suggest that the Energy Community has indeed facilitated important trust-building processes and genuine cooperation in Southeast Europe.
\end{abstract}

Keywords: Energy Community, sociological institutionalism, reconciliation process in the Western Balkans, energy policy Energiegemeinschaft, soziologischer Institutionalismus, Aussöhnungsprozess im westlichen Balkan, Energiepolitik

\section{Introduction}

$\mathrm{T}$

The Energy Community Treaty (ECT), which extends large parts of the EU acquis communautaire in the field of energy, competition and environment to Southeast Europe, ${ }^{1}$ is the first legally binding Treaty signed by all countries in the region. Thus, in addition to the expected added value in the energy sector, the protagonists of the ECT considered the Energy Community as "a milestone in reconciliation after the wars of the 1990s" (European Commission 2005). The core assumption that technical cooperation can contribute to peace and reconciliation in the Western Balkans was strongly shaped by the experiences in Western Europe, where cooperation in the coal and steel sector was the starting point of a unique integration process. Even if the situation in Western Europe in the 1950s differs from the current situation in the Western Balkans, the EU stresses that the

"Energy Community Treaty was consciously modelled on the European Coal and Steel Community [...]. The Treaty seeks to allow the states of post-war South East Europe to agree on one area of policy and then to develop in common a shared outlook" (European Commission, w.y.).

These broader political impacts expected of the Energy Community are what this article focuses on. Drawing on sociological institutionalism, a special focus will be on the identity- and trust-building effects expected to emerge from cooperation within the Energy Community. These 'ideational effects' are considered to be of utmost importance for the achievement of sustainable peace and stability in Southeast Europe. Thus, instead of evaluating the "hardware outcome"

* Daniel Göler is Professor for European Studies at the University of Passau; Kristina Kurze (M.E.S./M.A.) is Doctoral Candidate in Political Science at the University of Osnabrueck and Research Associate at the chair for Methods in the Social Sciences, University of Passau. This article has successfully undergone a double-blind peer-review process.

1 Founding members were the European Community, Croatia, Bosnia and Herzegovina, Serbia, Montenegro, the Former Yugoslav Republic of Macedonia, Romania, Bulgaria, Albania and Kosovo represented by the UN Interim Administration Mission in Kosovo (UNMIK). In 2010 and 2011 Moldova and the Ukraine respectively became full members of the Energy Community. Romania and Bulgaria have become participants after their accession to the EU in 2007. of the Energy Community (i.e. improvements in the energy sector), we are interested in tracing the "ideational outcome" of cooperation in the energy sector (i.e. trust-building effects, understanding, solidarity, reconciliation) (cf. Müller 2001: 175). To capture these ideational outcomes empirically, we will focus on two crucial cases of cooperation: the handling of Kosovo's independence declaration in 2008 within the Energy Community's institutions, and the gas crisis in January 2009. Both of the case studies are based on a range of primary sources such as official documents and reports, news coverage, policy-making processes and decisions taken within the Energy Community. For additional background information we have carried out five semi-structured interviews with officials from EU institutions and the Energy Community Secretariat at the beginning of 2011. Before turning to the case studies, we will give a brief overview of the Energy Community's evolution and internal set up.

\section{Background of the Energy Community}

The starting point of the Energy Community was the so-called Athens Process (Athens Memorandum 2002, 2003), which formed an integral part of the Stability Pact for Southeast Europe. Consequently the Athens Memorandum refers to the aim to "strengthen regional co-operation amongst the states and nations of South East Europe and to foster the conditions for peace, stability and economic growth" (Athens Memorandum 2002:1). Former Commissioner for Energy, Andris Piebalgs, stressed that the ECT was a "strategic decision to look at the long-term needs, to gather international consensus for a way forward and create a real basis for post-war cooperation" (Piebalgs 2006). Within the European Parliament the expectation was also expressed that the Energy Community could create a framework, in which "people in the region will also learn to cooperate with each other and thus minimise the risks of violent conflicts of the type seen in the past" (Lundgren 2006). European Commission President José Manuel Barroso even hailed the treaty as "a major achievement for peace and stability in Europe" (European Commission 2005). 
Thus, promoting peace and stability was obviously a central motive guiding the foundation of the Energy Community. The decision to choose energy policy as the technical policy area in which reconciliation and post-war cooperation should begin was driven by the fact that the energy sector was severely affected during the times of conflict: Large parts of the energy infrastructure were destroyed and the dissolution of former Yugoslavia separated the traditionally integrated energy markets. The necessary investments to solve these problems were, however, exceeding the means of the new states. Additionally, there is a high degree of complementarity between the various national energy markets and also some shared problems, such as the high degree of energy import dependency. Therefore, cooperation in the energy sector was considered a positive-sum game.

Against this backdrop the Energy Community Treaty seeks to establish open and transparent energy markets based on a common regulatory framework. In the short- and medium-term this should attract more investments into power generation and networks. The treaty also aims at the re-integration of the regional national energy markets. In the long-term, a full integration of the contracting parties into the EU's internal energy market is anticipated. All of these measures are expected to contribute to the overall energy policy goal of providing secure, sustainable and competitive energy supplies. In more concrete terms, contracting parties have committed themselves to implement large parts of the EU secondary law on energy, environment and competition. Among these are for instance the second internal market package, selected directives on environmental protection and the main antitrust and state aid rules. By now, the Energy Community acquis has already been extended to EU directives on security of electricity and gas supply, as well as energy efficiency. ${ }^{2}$ Hence the Energy Community follows a flexible and dynamic approach, which is possible not least due to its specific institutional design and decision-making procedures.

Looking at the institutional design of the Energy Community more closely, it becomes quite obvious that the EU institutions were taken as a blueprint. The most important institution is the ministerial council, which provides general policy guidelines, takes measures and adopts procedural acts. It consists of one representative of each contracting party and two representatives of the European Union (EU-member states' representatives can participate in the meetings without voting right); the Presidency is held by each contracting party for a term of one year (until 2010 six months). The work of the ministerial council is prepared by a Permanent High Level Group (PHLG), which is also responsible for technical assistance and the evaluation of the achievement of the objectives of the Treaty. Additionally, the PHLG can take measures, if so empowered by the ministerial council. A regulatory board is responsible for recommendations concerning cross-border disputes. Furthermore, the regulatory board advises the ministerial council and the PHLG on the details of statutory, technical and regulatory rules; it can also take measures, if so empowered by the ministerial council, and

2 For a complete list of EU rules adopted by contracting parties see: http:// www.energy-community.org/portal/page/portal/ENC_HOME/ENERGY_ COMMUNITY/Legal/EU_Legislation (last access: 06/02/2011). adopt procedural acts. The Energy Community has four fora (on oil, gas, electricity and social issues) as advisory bodies, which consist of interested stakeholders, regulators, industry representative groups, consumer and social organisations. The work of all these institutions is supported by a secretariat based in Vienna, which also acts as the guardian of the treaty by reviewing implementation and submitting yearly progress reports to the ministerial council.

This complex institutional setting underlines that the Energy Community Treaty is more than a mere international treaty to regulate specific energy questions. With the Energy Community the contracting parties shaped a new international organisation with a dense institutional structure (Göler/Kurze 2009b: 223). This high degree of institutionalisation is also reflected in the differentiated rules of decision-making. Especially the possibility of simple and qualified majority voting ${ }^{3}$ illustrates that the Energy Community goes beyond a mere arena of intergovernmental coordination.

Despite these institutional peculiarities the academic literature on the Energy Community has focussed mainly on energy policy issues, i.e. the effects on the EU's energy security (Fischer 2010: 1; Göler/Kurze 2009a: 432, Buchan 2009: 85) and the implementation of energy policy reforms in the Western Balkans (Busek 2007; Center for Strategic and International Studies 2007, Hofer 2008). Within the growing conceptual literature on 'external governance' the Energy Community is taken as an example of sectoral integration, by which the EU tries to (re-)organise its relationships with its neighbouring countries (Prange-Gstöhl 2009; Göler/Kurze 2009a,b; Fischer/ Lippert 2009: 68). Surprisingly, the declared contribution to peace and reconciliation in the Western Balkans is hardly covered in the academic literature (for an exception see: Renner 2009). This specific aspect will be discussed here drawing in particular on constructivist variants of institutionalism.

\section{Theoretical Framework}

Institutionalist approaches in political science are built around the "apparently banal claim" (Rosamond 2000: 113) that institutions matter. Besides this common assumption, institutionalism is, however, not a homogenous research approach (Hall/Taylor 1996: 5). On the contrary, "different institutionalisms operate with quite different views about the nature of reality and the relationship between structure and agency" (Rosamond 2000: 114). In this article we do not intend to engage in these metatheoretical debates, but rather seek to deduce insights concerning the potential impact of cooperation in the energy sector for peace and stability in Southeast Europe. To do so we nevertheless consider it necessary to briefly summarize core assumptions of rational choice institutionalism and sociological institutionalism respectively.

3 The Energy Community Treaty comprises three decision-making modes, depending on the issue: Unanimity, qualified majority voting (a majority has to include the vote of the EU) and simple majority (initiatives can only be taken by the European Commission, who may alter or withdraw its proposal at any time, what constitutes a factual veto right). See ECT, article 79-85. 
First of all, both have quite distinct definitions of institutions (Pollack 2009: 125). Rational choice institutionalists look primarily at formal political institutions. It is assumed that these institutions are created and maintained deliberately for the efficient performance of specific functions (e.g. reduction of transaction costs, provision of policy-relevant information) (ibid.: 126-127). Constructivist variants of institutionalism (i.e. sociological institutionalism) reject this purely functional explanation of institutional design and "define institutions much more broadly to include informal norms and conventions as well as formal rules" (ibid.: 126). In addition to these conceptual differences, the two variants of institutionalism are based on diverging assumptions about human behaviour. Generally speaking, rational choice institutionalists take actors as strategic utility-maximizers that select those options for action, which are most beneficial in terms of attaining their preferences. In contrast, sociological institutionalists stress that "human behavior is not fully strategic but bounded by an individual's worldview" (Hall/Taylor 1996:7). They are not denying that human behaviour is purposive or goaloriented but emphasize that the "choice of a course of action depends on the interpretation of a situation rather than on purely instrumental calculation" (ibid.: 8). In short, rather than following a "logic of consequentialism" actors are assumed to follow a "logic of appropriateness" (March/Olsen 2006).

Based on these core assumptions about the nature of institutions and action, distinctive hypotheses about the functions and effects of institutions can be generated, i.e. sociological and rational choice institutionalists offer different views about how institutions matter. According to the latter, institutions matter because they provide useful information, reduce uncertainty and thereby improve actors' instrumental calculations on which strategic action can then be based. Thus, institutions affect individual action by altering the expectations an actor has regarding actions and reactions of others. From a sociological institutionalist perspective, institutions matter because they facilitate appropriate behaviour by providing "moral or cognitive templates for interpretation and action" (Hall/Taylor 1996: 8). Through various interchanges and discussions among members of a given governance network "actors are said to develop shared cognitive maps, often embodying a sense of appropriate institutional practices" (ibid.:17). Put differently, "cooperation may change actors' identities, rather than just their payoff structure, and hence the prevailing security environment" (Zehfuss 2002:14). Whether these 'ideational effects' can be identified in practice is the question guiding the following analysis of cooperation within the Energy Community.

\section{Cooperation within the Energy Community Framework}

A cursory glance at the work of the Energy Community will give the impression that the Community works well: All institutions hold regular meetings, the conclusion of the meetings show that most of the topics on the agenda are covered successfully and the implementation of the legislation in the contracting parties is preceding more or less successfully, too. Undoubtedly, there are some shortcomings in complying with the energy aquis, but bearing in mind the shortcomings in liberalising energy markets in EU member states (European Commission 2007), these problems should not be overrated.

However, to evaluate whether the Energy Community contributes to peace and reconciliation in Southeast Europe, it is not sufficient to look only at the 'hardware outcome'. Instead, one has to look at the cooperation processes itself. Thus, the process of cooperation in two cases will be analysed, in which one could expect that cooperation is affected or undermined by delicate political questions and mutual mistrust: First, the impact of the major current political issue in the Western Balkans, namely the declaration of independence by Kosovo in February 2008, on the work of the Energy Community's institutions. Second, the gas crisis in January 2009 has been chosen as a more recent example of a highly critical energy situation in Southeast Europe. It is assumed that dealing with both of these issues requires more than 'pseudo' or 'shallow' cooperation on paper, but requires genuine trust and solidarity among members of the Energy Community. Thus, the handling of these two cases should show whether or not the Energy Community has affected mutual perceptions and trust-building among its members.

\subsection{Dealing with Political Conflict: The Case of Kosovo}

The declaration of independence of Kosovo was a very critical point in the peace process in the Western Balkans. Hence, aggressive reactions by Serbia were considered possible. Similarly, negative impacts on Bosnia and Herzegovina were possible, where the parliament of the Republika Srpska adopted a resolution to take Kosovo as a precedent for Bosnia, in case a majority of EU member states recognised independence (Priznanje Kosova i referendum u RS 2008). The first problem to be solved in the context of the Energy Community was the representation of Kosovo. Considering the fact that Serbia, but also Bosnia and Herzegovina, did not recognise Kosovo - the EU did not adopt a common position either the members of the Energy Community agreed that Kosovo should continue to be represented by UNMIK. Additionally, all official documents continue to use the term contracting parties instead of member states. According to background talks with EU and Energy Community officials, the 'Kosovo-status question' arises occasionally in meetings, for example when the Kosovo delegation uses the label Republic of Kosovo and the Serbian delegation in turn underlines its counter-position. Yet, following the principal of 'agreeing to disagree,' both parties cooperate pragmatically in the Energy Community institutions. A participant of internal meetings illustrates this by citing a statement from the Serbian delegation: "We have political differences but when it comes to cooperation we cooperate" (Neykov 2011).

Thus, so far, the work of the Energy Community has not been blocked by the declaration of independence. This has also been 
confirmed by Energy Community staff as well as EU-officials. ${ }^{4}$ So far there was no discontinuation of meetings at the working level. In the regulatory board one could even recognise a rise of meetings after Kosovo's declaration of independence in February 2008. Moreover, in the decision-making process no major deadlock due to the 'Kosovo issue' occurred. In contrast, it was quite surprising that not only the implementation of the EU energy acquis proceeded, but there was even a widening of the Energy Community's scope of action in the aftermath of the independence declaration: In December 2008, the Ministerial Council made the decision to establish an oil forum (MC-EnC 2008a), and in November 2008 the first meeting of the social forum took place (Social Forum of the Energy Community 2008). Other important developments were the procedural act on rules for dispute settlement in June 2008 (MC-EnC 2008b) and the establishment of a security of supply coordination group in December 2008 (MC-EnC 2008c). Despite the public rhetoric before the proclaimed secession of Kosovo, Serbian representatives played an active role and cooperated in a constructive way with Kosovar representatives within the Energy Community framework. For instance, Serbia proposed an initiative for a regional energy strategy. This proposal stressed the importance of the Energy Community for the stabilisation process, emphasising that the "energy sector was selected as the pillar for upgraded cooperation between the countries of the region [... and for] reconciliation" (ibid.). The Serbian initiative of such an energy strategy as well as the positive reactions of the other contracting parties suggest both a decreasing level of mistrust and changing perceptions between the members of the Energy Community.

Another example showing that the 'Kosovo question' does not prevent practical cooperation within the Energy Community can be seen in the recent enlargement of the Energy Community. In 2010 and 2011 Moldova and the Ukraine became full members of the Energy Community, which reflects to some extent the attractiveness of the Community itself. But what is important to note here is that all contracting parties were in favour of the accession of Moldova and the Ukraine. The fact that both states do not recognise the independence of Kosovo did not play any role in the accession talks.

Still, there are of course unresolved issues, for example the recognition of the Kosovo system operator by the Serbian operator (EMS and KOSTT), which has led to conflicts about compensations between the two operators. These problems also affect the long-term plan to establish a Coordinated Auction Office in Southeast Europe. ${ }^{5}$ Yet, these issues did not lead to a major deadlock in cooperation; they are currently dealt with under the regulations of the dispute settlement procedure, ${ }^{6}$ which in turn illustrates the commitment to common rules and norms. To subject oneself (in the dispute settlement procedure)

4 The interviewees preferred not to be cited directly.

5 The project of establishing a Coordinated Auction Office centres essentially on the implementation of the principles of the EU internal market regulation concerning the "conditions for access to the network for cross-border exchanges in electricity" (Regulation (EC) No 1228/2003).

6 Pending Case No.01-06/11, for further information see: http://www.energycommunity.org/portal/page/portal/ENC_HOME/ENERGY_COMMUNITY/ Dispute_Settlement/01_06_11 (last access: 06/02/2011); for details concerning the dispute settlement procedure see Title VII of the ECT and Procedural Act no. 2008/01/MC-EnC. to the decision of the ministerial council requires a high degree of trust, especially if one takes into account that the decision is made without the vote of the parties concerned. Even if there are only a few dispute settlement cases pending, it nevertheless shows that the principles of this procedure are accepted by all contracting parties (Energy Community Secretariat 2010).

What underlines the changed situation in the region even more strongly is the following: Bearing in mind that Kosovo depends completely on electricity from Serbia and considering the very emotional debate in Serbia about Kosovo, it can be regarded as a success - or better as a proof of changing attitudes that even in the days of Kosovo's independence declaration, Serbia observed the obligations under the ECT and did not use energy supply cuts as an instrument to create political pressure. The following case study will deal in more detail with energy security and its implications for trust-building processes in the Energy Community.

\subsection{Ensuring Energy Security: The Case of the Gas Crisis 2009}

Energy security has re-emerged as one of the most critical issues in energy policy debates in Europe. And indeed, "securing energy supply through solidarity constitutes one of the main objectives of the Energy Community" (MC-EnC 2008c). However, actually cooperating in such a sensitive policy area poses a great challenge, especially against the problematic historical background that strategic energy supply cuts were evidently used during the wars. Especially in Sarajevo the enduring supply shortages produced dramatic living-conditions as a local journalist reported:

"Do whatever you can to stop the killing, to bring about peace, and then bring us trees. There aren't any left in Sarajevo. All city trees, all parks, have been cut for wood to give some warmth to people freezing in a city with no windows, no gas, no electricity." (Kurspahic 1997).

Against this backdrop it could hardly be expected that the former conflict parties would seek to develop a common energy security strategy, which inevitably creates mutual vulnerabilities. Instead one could expect the striving for energy autarchy as a symbol of sovereignty and independence. However, by reducing the risks of political misuse of energy resources, the Energy Community offers an alternative approach to energy security. Furthermore, the regulations concerning security of supply in the ECT include certain trust-building measures.

Firstly, all of the contracting parties have to publish so-called 'security of supply statements' (ECT, Art. 29), in which they openly declare the level of domestic production capacities, levels of import dependency and the geographic origin of imported fuels. Secondly, contracting parties have also agreed to notify each other if safeguard measures are being taken in cases of supply crises (ECT, Art. 36-39). Thus, contracting parties have committed to standardised procedures in the event of sudden supply disturbances, meaning they have to consider the impacts of their actions on the energy supply situation and energy markets of the Energy Community as a 
whole. Hence, a purely national outlook on energy security and crisis management is no longer acceptable as a member of the Energy Community. The director of the Energy Community Secretariat, Slavtcho Neykov, described this as a "shift from energy nationalism toward energy regionalism" (Neykov 2011). The third set of measures is concerned with 'mutual assistance' in times of crises (ECT, Art. 44-46). Currently, discussions in the Energy Community concerning the concrete operationalisation of the 'mutual assistance clauses' are still continuing. The establishment of a regional 'Security of Supply Coordination Group' should enhance the work on the development of common "crisis management measures" (MC-EnC 2008c). All these mechanisms and Treaty provisions indicate that there is a strong and serious commitment to improve and develop common approaches to security of supply in Southeast Europe. This indicates a change of perception among the contracting parties: When it comes to energy security, they perceive each other more and more as partners rather than as competitors or even enemies.

This ideational change has also become obvious in practice. Only a few weeks after the official establishment of the Energy Community's "Security of Supply Coordination Group" one of the most severe energy supply crises hit Europe, caused by a conflict between Russia and Ukraine. For almost two weeks gas supplies were low and for a few days in January 2009 even cut completely. In Southeast Europe such a supply crisis was expected to cause very serious problems, in particular because in many instances the only alternative to replace gas supplies was to switch to electricity. Hence, a 'double energy crisis' - a shortage of gas and overloaded electricity grids - could have occurred. This serious and realistic risk, however, did not lead to so-called 'sauve qui peut'-politics as was the case in Western Europe during the oil crises in the 1970s (Kurze 2009: 104). Instead, the situation was handled in a coordinated manner (Euractiv 2009). Besides the important exchange of all necessary information, there have also been direct ways of assistance, such as the provision of electricity to stabilise the grids or the delivery of gas from Serbia to Bosnia and Herzegovina, which "has been highlighted by observers as a very important political gesture" (ibid.). Additionally, the close cooperation and the success in preventing a regional blackout created a kind of 'team spirit' at the working level, as a member of the Energy Community Secretariat reported:

"Many experts were on leave for the Orthodox Christmas celebrations at the time of the crisis. But they all provided the necessary information, working from their home computers or by going to the office" (ibid.).

In terms of ideational outcomes, the common handling of the gas crisis was perceived as a proof that one can trust each other even in critical situations. Beyond the immediate positive experience of a coordinated crisis management, the gas crisis may also have a lasting trust-building effect, as the director of the Energy Community pointed out (Neykov 2011). Thus, the increased level of trust may constitute a highly valuable 'political resource' in handling potential energy crises in the future.

\section{Conclusions}

The Energy Community has created a dense network of cooperation between parties, which had been at the status of war 10 to 15 years ago. It might be considered as surprising that history and current political conflicts do not prevent practical cooperation, as the previous empirical case studies show. Especially the continuing cooperation in politically delicate situations such as Kosovo's declaration of independence can be considered as a proof that former hostilities and mistrust could be reduced. According to background talks, changes in mutual perceptions and attitudes - especially at the working-level result from the fact that the same set of committed people have worked together intensively over the past five years. Thus, the history of conflicts is incrementally supplemented - and to some extent even replaced - by a history of cooperation. At the level of the ministerial council, this situation differs to some degree. Political status questions and principal disagreements stemming from conflicts of the past may still complicate cooperation processes today, as the failure to establish a Coordinated Auction Office illustrates. But even at the political level the experiences of successful cooperation changed the attitudes. The director of the Energy Community Secretariat stressed these developments by stating that "the level of trust is completely different compared to the beginning. [Participants] exchange information much more openly [and] are much more open for criticism" (Neykov 2011). On this basis, even sensitive issues such as energy security could be handled within the framework of the Energy Community. Considering that a common energy security policy implicates mutual vulnerability in a highly security-relevant area, these activities indicate that the level of trust has increased among the members.

Summarising the main findings of the two case studies one can conclude that the Energy Community is far more than a mere functional framework to coordinate energy issues. The experiences of intensive and continuous cooperation and the successful common handling of energy problems have generated a situation in which conflicts of the past fade to influence present-day cooperation and mutual perceptions are changing. To conclude, the Energy Community is certainly not the place where highly political conflicts are solved, but it facilitates important trust-building processes that are indispensible to genuinely deal with more critical political problems. In this manner the Energy Community does contribute to peace and stability in Southeast Europe.

These findings underline the theoretical assumption that institutions do not only matter because they provide useful information, reduce uncertainty and thereby improve actors' instrumental calculations, but that they also matter because the experiences of cooperation change actors' perceptions and attitudes. The creation of a kind of 'team spirit' during the gas crisis in 2009 can be considered as an empirical illustration of these ideational effects. That such changes are possible even against historical problematic backgrounds underlines the strengths of sociological institutionalism for the analysis of regional cooperation.

Even if history will never repeat itself, the developments in the context of the Energy Community resemble the beginnings of 
the European Union, where cooperation in the coal sector was the starting point of a unique reconciliation and integration process. The empirical findings presented in this article largely confirm the conclusion of Meglena Kuneva, former European Commissioner, that the "Energy Community is not only about energy and markets. It is also about regional cooperation, mutual trust, synergies and reconciliation" (Kuneva 2009).

\section{Bibliography}

Athens Memorandum (2002): Memorandum of Understanding on the Regional Electricity Market in South East Europe and its Integration into the European Union Internal Electricity Market, Athens; http://www.stabilitypact.org/energy/041011bucharest/athens-memorandum2002.pdf (last access: 06/02/ 2011).

Athens Memorandum (2003): Memorandum of Understanding on the Regional Energy Market in South East Europe and its Integration into the European Community Internal Energy Market, Athens (http://www.stabilitypact.org/energy/031208mou.pdf, last access: 06/02/2011).

Buchan, David (2009): Energy und Climate Change. Europe at the Crossroads, Oxford.

Busek, Erhard (2007). Energiesicherheit in Südosteuropa, in: Reinhard C. Meier-Walser (Ed.): Energieversorgung als Sicherheitspolitische Herausforderung, Munich, pp. 267-273.

Center for Strategic and International Studies (2010): Re-linking the Western Balkans: The Energy Dimension, Policy-Report, Athens.

Euractiv (2009): 'Miracle' saved Balkans from blackout during gas crisis, 19.3.2009, (http://www.euractiv.com/en/energy/ miracle-saved-balkans-blackout-gas-crisis/article-180421, last access: 06/02/2011).

European Commission (2005): The EU and South East Europe Sign a Historic Treaty to Boost Energy Integration (IP/05/1346), Brussels.

European Commission (DG TREN) (w.y.): South East Europe connects the internal market for electricity and gas. Memo, Brussels.

European Commission (2007): Communication from the Commission to the Council and the European Parliament. Prospects for the internal gas and electricity market, COM(2006) 841 final, Brussels.

European Parliament (2006): Plenary Debate, Wednesday, 17 May 2006, Strasbourg.

Treaty Establishing the Energy Community, (http://www.energycommunity.org/portal/page/portal/ENC_HOME/ENERGY_ COMMUNITY/Legal/Treaty (last access: 06/02/2011)

Energy Community (PHLG Meeting) (2006): Security of Gas Supply (SoS) in See in the Short Term, Vienna (http://www. energy-community.org/pls/portal/docs/55849.PDF, last access: 06/02/2011).
Energy Community Secretariat (2010): Report on Dispute Settlement, Vienna, (www.energy-community.org/pls/portal/ docs/724180.pdf, last access: 06/02/2011).

Fischer, Severin (2010): Internal and External Regionalisation of Energy Policies. The European Union's Market Governance Approach, IEP Working Paper 03/2010, Berlin.

Fischer, Severin/Lippert, Barbara (2009): Mehr Gleise: EU-Energieaußenpolitik und Nachbarschaftspolitik der EU, in: Osteuropa 11/2009, pp. 53-69.

Göler, Daniel/Kurze, Kristina (2009a): Die EU als transnationaler Polity-Shaper. Über die Schaffung sektoraler Governance-Strukturen am Beispiel der Energiegemeinschaft, in: Österreichische Zeitschrift für Politikwissenschaft, 4/2009, pp. 423-436.

Göler, Daniel/Kurze, Kristina (2009b): Die europäische Energiegemeinschaft: Ein Modell zur Ausgestaltung der Östlichen Partnerschaft?, in: Krakowskie Studia Miedzynarodowe 4/2009, pp. 217-227.

Hall, Peter A./Taylor Rosemary C.R. (1996): Political Science and the Three New Institutionalisms, MPIFG Discussion Paper 6/1996, Cologne.

Hofer, Stephan (2008): Die Europäische Union als Regelexporteur. Die Europäisierung der Energiepolitik in Bulgarien, Serbien und der Ukraine, Baden-Baden.

Kuneva, Meglena (2009): Making energy markets work for consumers. Lecture at Energy Community Secretariat. Vienna, 15 May 2009 (http://www.energy-community.org/pls/portal/ docs/332196.PDF, last access: 06/02/2011).

Kurspahic, Kemal (1997): As Long as Sarajevo Exists, Stony Creek.

Kurze, Kristina (2009): Europas fragile Energiesicherheit. Versorgungskrisen und ihre Bedeutung für die europäische Energiepolitik, Münster.

Lundgren, Nils (2006): Statement in the European Parliament, in: European Parliament, Plenary Debate, Wednesday, 17 May 2006 , Strasbourg.

March, James G./Olsen, Johan P. (2006): The Logic of Appropriateness, in: Rein, Martin/Moran, Michael/Goodin, Robert E. (Eds.): The Oxford Handbook of Public Policy. Oxford. pp. 689-708.

MC-EnC (Ministerial Council of the Energy Community) (2008a): Decision 2008/03/MC-EnC.

MC-EnC (2008b): Procedural Act no. 2008/01/MC-EnC.

MC-EnC (2008c): Procedural Act no. 2008/02/MC-EnC.

Müller, Harald(2001): International Relations as Communicative Action, in: Fierke, Karin M./Jørgensen, Knud Erik (Hrsg.): Constructing international relations - the next generation, Armonk/N.Y, London.

Neykov, Slavtcho (2011): Interview with Slavtcho Neykov, Director of Energy Community Secretariat, 27.1.2011.

Piebalgs, Andris (2006): Statement in the European Parliament, in: European Parliament, Plenary Debate, Wednesday, 17 May 2006, Strasbourg. 
Pollack, Mark A, (2009): The New Institutionalisms and European Integration, in: Antje, Wiener/Diez, Thomas (Eds.): European Integration Theory. Oxford. pp. 125-143.

Priznanje Kosova i referendum u RS (2008); in: B92(online) vom 22. Februar 2008 (http://www.b92.net/info/vesti/index.php ?yyyy $=2008 \& \mathrm{~mm}=02 \& \mathrm{dd}=22 \& n a v \_i d=285932$, last access: 06/02/2011).

Renner, Stephan (2009). The Energy Community of Southeast Europe: A neo-functionalist project of regional integration, in: European Integration online Papers, 1/2009, Vienna (http:// www.eiop.or.at/eiop/index.php/eiop/article/view/2009_ 001a/88, last access: 06/02/2011).
Republic of Serbia (Ministry of Mining and Energy) (2010): Proposal for Regional Energy Strategy, Belgrade.

Rosamond, Ben (2000): Theories of European Integration, Houndmills/Basingstoke.

Social Forum of the Energy Community (2008): Conclusions of the First Social Forum, 18-19 November 2008, Tirana.

Winkler, Hans (2008): Statement in the European Parliament, in: European Parliament, Plenary Debate, Wednesday, 17 May 2006, Strasbourg.

Zehfuss, Maja (2002): Constructivism in international relations, Cambridge.

\title{
Europeanization from Below
}

\section{The Formation of Gender Equality Policies in the Western Balkans}

\author{
Anne Jenichen*
}

\begin{abstract}
The article argues that, compared with the other countries in the Western Balkans, the Europeanization of gender equality policies in Bosnia and Herzegovina represents an interesting case of "Europeanization from below". It was not the EU, which called for the introduction of gender equality policies in the Stabilization and Association Process, but domestic policy entrepreneurs, who constructed a "shadow of membership conditionality". They framed their requests as element of the accession process tapping into the aspiration of policy-makers to joining the EU. The case illustrates that Europeanization matters in the Western Balkans, not only in terms of a direct influence of the EU but also because it provides opportunities for domestic policy entrepreneurs to further European objectives themselves.
\end{abstract}

Keywords: Europeanization, gender equality policies, Western Balkan, Bosnia and Herzegovina, domestic policy entrepreneurs Europäisierung, Geschlechtergleichstellungspolitiken, westlicher Balkan, Bosnien und Herzegowina, inländische PolitikunternehmerInnen

\section{Introduction}

S cholars have attached a great deal of importance to membership conditionality when debating the effectiveness of the European Union (EU) in its Eastern enlargement process (Ethier 2003; Kelley 2004a, 2004b; Schimmelfennig/Sedelmeier 2004; Schimmelfennig 2005; Vachudova 2003). Less attention has so far received the question of how Europeanization changes the preferences and strategies of domestic actors, which themselves develop an interest in advancing Europeanization in their policy fields without being subject to direct top-down adoption pressure from the EU. The comparative analysis of the Europeanization of gender equality policies in South Eastern Europe reveals an interesting case of "Europeanization from below" (Georgakakis/Weisbein 2010) and of the "strategic, legitimizing usage of Europe" (Woll/Jacquot 2010): In Bosnia and Herzegovina (BiH) it was

* Dr. des. Anne Jenichen is senior lecturer and researcher at the Jean Monnet Centre for European Studies (CEuS), University of Bremen. This article has successfully undergone a double-blind peer-review process. not the EU, which put gender equality policies onto the agenda but domestic policy entrepreneurs from non-governmental organizations (NGO), political parties and governmental institutions responsible for the advancement of gender equality. They strategically framed their requests as element of the accession process to European organizations, thus tapping into aspirations of the Bosnian government to joining the EU. In this "shadow of membership conditionality", domestic policy entrepreneurs decisively contributed to the initiation, formulation and adoption of respective laws and policies, regardless of the direct influence of the EU itself.

Before turning to the Bosnian case, the next section provides a brief overview of the Europeanization process of gender equality policies in the Western Balkans, also revealing the peculiarity of $\mathrm{BiH}$ in that regard. The subsequent section focuses on the strategic discursive action by Bosnian policy entrepreneurs. The article concludes with a brief discussion of the potential of a repeated application of their strategies in other policy fields and some policy implications for the Europeanization of gender equality policies in the Western Balkans. 